\title{
How to Improve Listening Skills for Technical Students
}

\author{
$\underline{\text { http://dx.doi.org/ijep.v1i3.1795 }}$ \\ G. Artyushina, O. Sheypak, A.Khovrin and V.Spektor \\ «MATI»-Russian State Technological University named after K. E. Tsiolkovsky, Moscow, Russia
}

\begin{abstract}
Communication competence includes four main activities: speaking, listening, reading, and writing. Listening is the most difficult skill for many of our students. But that of the time a person is engaged in communication, approximately $9 \%$ is devoted to writing, $16 \%$ to reading, $30 \%$ to speaking, and $45 \%$ to listening. That's why for nonlinguistic universities the perfection and development of the speech learning procedure becomes actual especially when we use academic hours of student independent work (selfstudy) for this purpose.
\end{abstract}

Index Terms-higher education, listening skills, mobile technologies, podcasting, student motivation.

\section{INTRODUCTION}

To understand a foreign speech is a key moment to develop speaking skills. It has been proved that if a person is listening and reading materials on the same topic he masters grammar and vocabulary faster and better. Today there are a lot of methods to improve listening skills. The eight shown in Figure 1 are the most effective.

At the same time the role of listening for comprehension and development of the ability to understand and participate in spoken communication encourage teachers to answer some questions:

- Why students find listening difficult?

- How can we help students build confidence in dealing with authentic spoken English?

- What kind of audio files will help develop listening ability?

The first problem can be explained by the following five statements:

- Students try to listen and understand word by word.

- Students assume failure.

- Students do not have an idea of the listening context.

- Students are not conscious of features of connected speech, word stress, or speed of speech.

- Students are not aware of the listening strategies.

Besides, it was necessary for teachers to motivate students to improve their listening skills. So, we had to choose the adequate means of training that don't make listening difficult but create favourable psychological environment to listen to foreign language audio files. The main step to create motivation is to choose audio file correctly. On the one hand, too difficult texts can cause discouragement of students. On the other hand, the absence of difficulties makes listening uninteresting and unattractive.

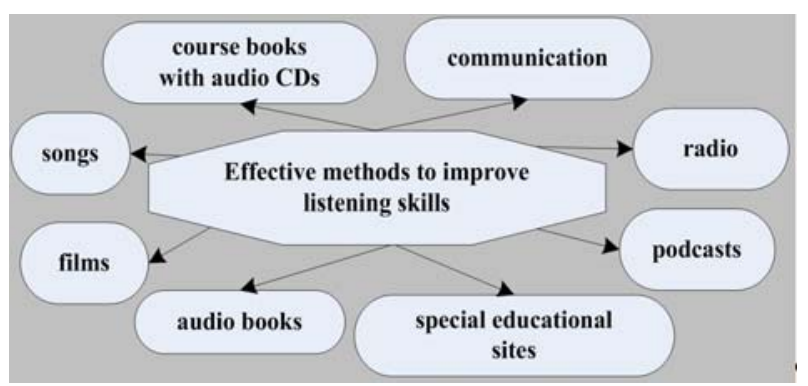

Figure 1. The most effective methods to improve listening skills

The topic of the audio file is important, too. Also, the efficacy of the listening increases if it is easy "to drill" the material anywhere, anytime learning [1]. It was Wesly A.Fryer who said, "The real power of audio podcasts comes not only from their publication for a potentially global audience via the Internet, but also from the ability listeners have to time and place shift when they enjoy podcasts. Using portable digital music players, anyone can listen to a podcast in their car, at the gym, or while multitasking during some other activity" [2]. This interpretation tends to be correct as to have found the solution of practically all didactical problems being discussed above in ELT (English Language Teaching) Podcasts.

\section{ELT PODCASTING}

The first podcast appeared in early 2005. Nowadays they are audio programmes on the Web. All episodes can be listened to on the computer, or downloaded to an MP3 or iPod for later listening. The current generation has grown up and lived with digital technology The fact that most of today's students are digital natives and familiar with downloading audio files from the internet and own their own audio players makes the adoption of this method of learning almost automatic.

ELT podcasts are particularly suited for extensive listening to motivate student interest in listening to the English language and providing them with exposure to native speakers' speech. This activity effectively bridges the gap between the formal English which dominates in most language classrooms and the informal English used in most real-life communication events.

ELT podcasts permit students to access educational materials only at home but also while walking to the university, or doing any activity they choose. They can play the recording at any time which is convenient to them. Podcasts have an obvious place in distance education, fulfilling the same role that audio cassettes performed in a previous era. Educators saw the huge potential they have for teaching and learning [3], [4]. 
But there are some disadvantages and the main that the podcasts are not interactive It is a one-way delivery which precludes student interaction so, it is a type of nonparticipatory listening to live conversations without taking part. Since podcasting is an extension of the traditional didactic model of education and can lead to deep learning of English.

\section{THE PODCASTING IMPLEMENTATION}

Our experiment in podcasting took place in the subject "General English". There were a total of 180 students from the department "Youth policy and Social Technologies" undertaking the subject. Because those were firstyear students support for students' learning was given the highest priority. That's because many students have difficulty making the transition from the high school learning environment to university. At school they receive a great deal of one-on one support from teachers whereas at university the environment is strange, student numbers in groups are large and lectures have too many teaching, research, and administrative duties to take a personal interest in every single student. At universities student are expected to be adult learners, self-directed and selfmotivated.

Another reason for podcasting was to engage students in the latest and most up-to-date technology. So, encouraging students to use mobile technology is appropriate.

The other reason is the contents of the General English curriculum. It comprises 10 credits, 4 of them are classroom, face-to-face interactive activity. How to fill the remaining 6 credits for self-studies? For these special Guides were developed. One of them is 'Guide to Listening" consisting of 16 podcasts taken from the educational site www.eslpod.com.

Each podcast has an up-to-date topic, such as "Time management", "Business E-mails and abbreviations", "Job applications", and etc. The duration of the recordings varies in length from 13 minutes to 16 minutes. The students are expected to spend 4 academic hours to do all the tasks themselves. As "Guide to Listening" is an obligatory component of the English language curriculum the level of students' knowledge was checked up. At the end of each semester all students were to complete a test form.
Besides, the students were surveyed about their opinion on ELT Podcasts. The comments were very encouraging. The key idea of the survey forms is that podcasts were very useful because you can transfer the file into MP3 and you can always enjoy with it. The main use of podcasting - anytime, anywhere learning - was supported by the survey, too.

\section{CONCLUSION}

Podcasting as a new technology has huge potential in enhancing student's listening skills. The ease for downloading podcasts with authentic materials means that now our students can be engaged in plenty of listening practice. We, as educators, need to take into account that mobile technologies in English language teaching motivate students to develop and improve their listening skills, create atmosphere of success and stimulate their educational activity.

\section{REFERENCES}

[1] L.E.Dyson.and I Nataatmadja,"Student motivation in Podcast use", IMCL2008 Conference, 16-18 April 2008, Amman, Jordan

[2] W.Fryer, "Classroom Audio Podcasting”, from http://www.speed ofcreativity.org.

[3] C. Adams, "Geek's guide to teaching in the modern age," Instructor, 115(7), pp.48-51.

[4] D. Jobbings, "Exploiting the educational potential of podcasting," Retrieved January 7, 2007, from http://www.recap.ltd.uk/articles.

\section{AUTHORS}

G. Artyushina is with the "MATI"-Russian State Technological University named after K.E.Tsiolkovsky, Moscow, Russia, (e-mail: gartyushina@gmail.com).

O. Sheypak, is with "MATI"-Russian State Technological University named after K.E.Tsiolkovsky, Moscow, Russia, (e-mail: oasheypak@gmail.com).

A. Khovrin is with the "MATI"-Russian State Technological University named after K.E.Tsiolkovsky, Moscow, Russia, (e-mail: hovrinayu@mati.ru).

V. Spector is with the "MATI"-Russian State Technological University named after K.E.Tsiolkovsky, Moscow, Russia, 121552 (e-mail: spektorvs@mati.ru).

Received 22 August 2011. Published as resubmitted by the authors 26 September 2011. 